\title{
JEAN AND JOHN HODGES
}

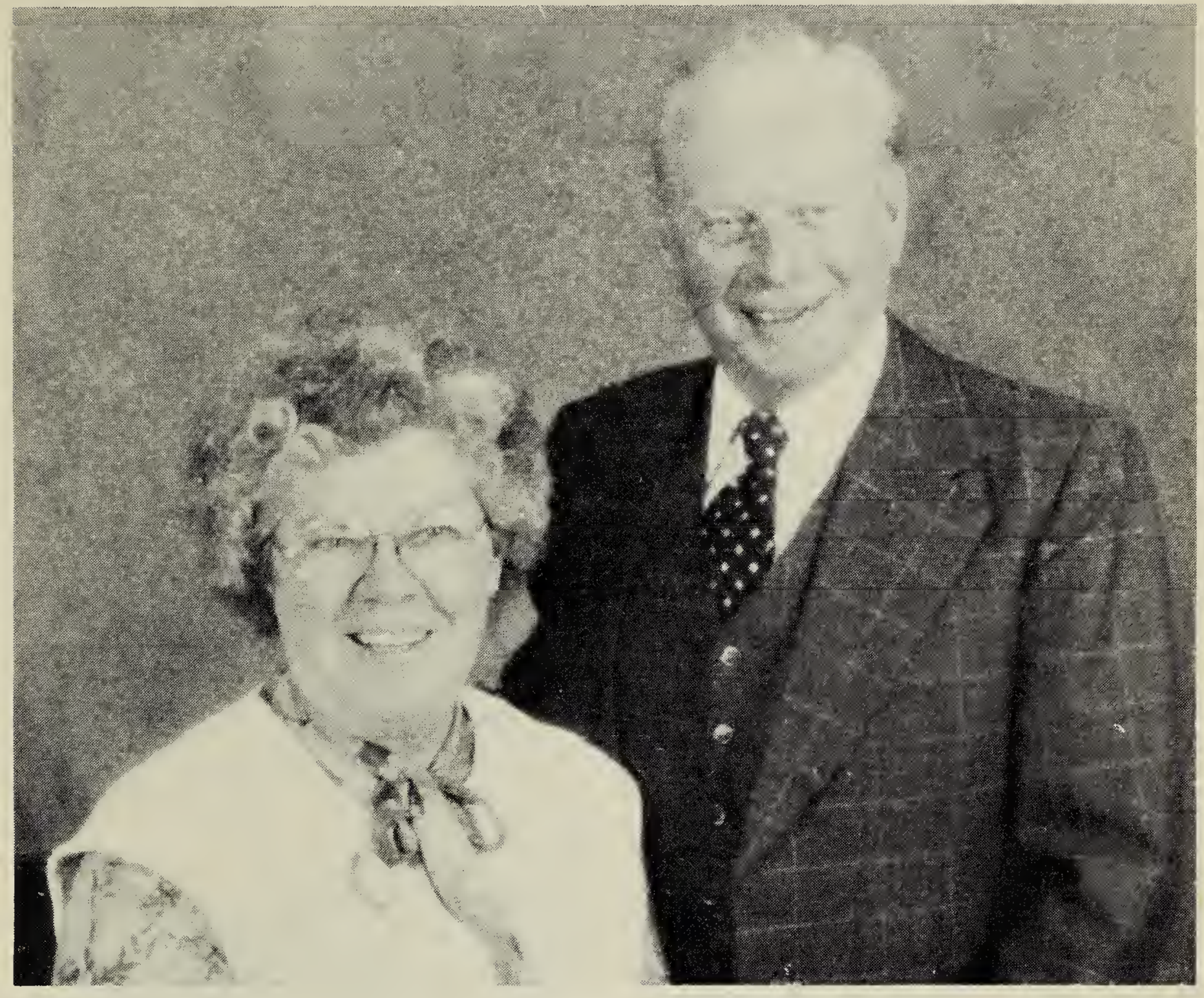

In a short nine months, Saskatchewan lost two very good friends who were active throughout their lives in many aspects of natural history: Eleanor Jean Hodges (August 1982) and John Victor Hodges (April 1983).

John was born in 1918 in Belfast, Ireland, and after the family immigrated to Saskatchewan a few months were spent on a farm after which they moved to Regina where John lived (with the exception of war service) to the end of his life.

Jean was born in 1920 at Mud Lake, near Kelliher, later moving to Canora where she attended public school before moving to Regina.
Both Jean and John attended Scott Collegiate where she was active in academic subjects and sports while John continued to pursue the scientific interests he had begun at Albert School. These included a fine butterfly collection which he obtained in various places including Government House and the Legislative flower beds; run ins with head gardeners resulted until they realized how serious this red headed boy was! At this time too he began collecting Indian artifacts and systematically cataloguing them. While at Scott, his interest in astronomy began to develop and he was instrumental in salvaging the observatory from Central Collegiate which remained in his pos- 
session. Also while in his teens, he was introduced by the pathologist then at the General Hospital to scientific laboratory work; thus began his concern for his fellow man which showed up continually in his later life.

Before the second world war, John joined the militia; he was a crack shot and Jean often joined him, both winning competitions in teams and as individuals. At the same time John was taking a machinist and mechanics course at Balfour Technical School which stood him in good stead when he enlisted in the RCAF. He spent most of his tour of duty as a Flight Sergeant gunnery instructor living in married quarters with Jean and their children, Gerry and Faye, some of the time. He was posted to Leeds, England, for the last nine months of the war. When he returned, he attended Regina College.

In common with many returned service men, John worked at a number of jobs including film making of hospital operating procedures for teaching purposes. He spent a number of years with the Workers' Compensation Board then moved to Canada Labour in the same vital field of safety in the work place.

During the fifties, sixties and seventies, John and Jean continued to work as a team in organizations including Saskatchewan Natural History Society, Regina Natural History Society, Saskatchewan Archeological Society, Regina Archeological Society, Regina Astronomical Society and Regina Guild of Color Photography. In some cases they were founding members; always held office, attended meetings, lectured and participated wherever they were. Both lectured for Adult Education, New Horizons and Community. College. John lectured to RCMP Police College, to University of Regina classes and as guest lecturer for other organizations, with Jean doing much of his research. Jean helped many Girl Guide members get their "star" badges and spent several years sharing the natural wonders of our province with students touring the Saskatchewan Museum of Natural History. Other activities of this unusual couple included membership in Masonic Lodge, Assiniboia No. 49 AF and AM by John and Jean's membership in Eastern Star, Excelsior Chapter. For many years, John was a member of the Associate Committee of Meteoritics, National Research Council of Canada; and was made an associate of Saskatchewan Safety Engineers. In 1951, John joined the St. John's Ambulance Association where he quickly advanced to be instructor of advanced first aid. Jean also participated as a first aid instructor in the early sixties including teaching industrial first aid in the field for the oil drilling industry. John was honored three times by the Order of St. John of Jerusalem twice being decorated by the GovernorGeneral of Ganada, Rt. Hon. George Vanier in Ottawa. Then a special investiture was held in the chapel of the Plains Health Centre on April 6, 1983. In the presence of his son, officers of the order and close friends, John was invested in the order of Commander-Brother by His Honour Irvin McIntosh, Lieutenant Governor of Saskatchewan. This is one of the highest honours attainable and must be approved by Her Majesty, Queen Elizabeth.

Although they were "amateur" archeologists, the Museum of Natural History asked John to conduct the Last Mountain House "dig" as director influenced no doubt by his work at other sites especially at Stoney Beach. Jean acted as one of his site supervisors for the five years the project continued and, hopefully, a report of this work will be published soon. 
The basement of the Hodges' home was always a hive of activity with friends grinding mirrors for telescopes, transcribing the journal for the Hudson's Bay post at Last Mountain House, or reconstructing pottery shards into recognizable pots (Jean's speciality). Whether friends were developing films or recording facts which added to our knowledge of our province, there was always laughter and a feeling of achievement. In later years, award-winning photographs and Jean's water colors began to appear in the living room where so many meetings of societies had been held.
John and Jean's friends and acquaintances will remember them for their many interests and expertise in so many fields of knowledge. They will also remember John's ability to teach techniques of investigation and research and Jean's help and hospitality. I shall always remember their patience as they taught me to feed chickadees from the hand and the reward when a bird pauses on my fingers, seed in beak, and looks at me as if to say: thank you! A friend, Elizabeth Parkin, Regina.

\section{EDWIN WILLIAM BROOMAN, 1914-1983}

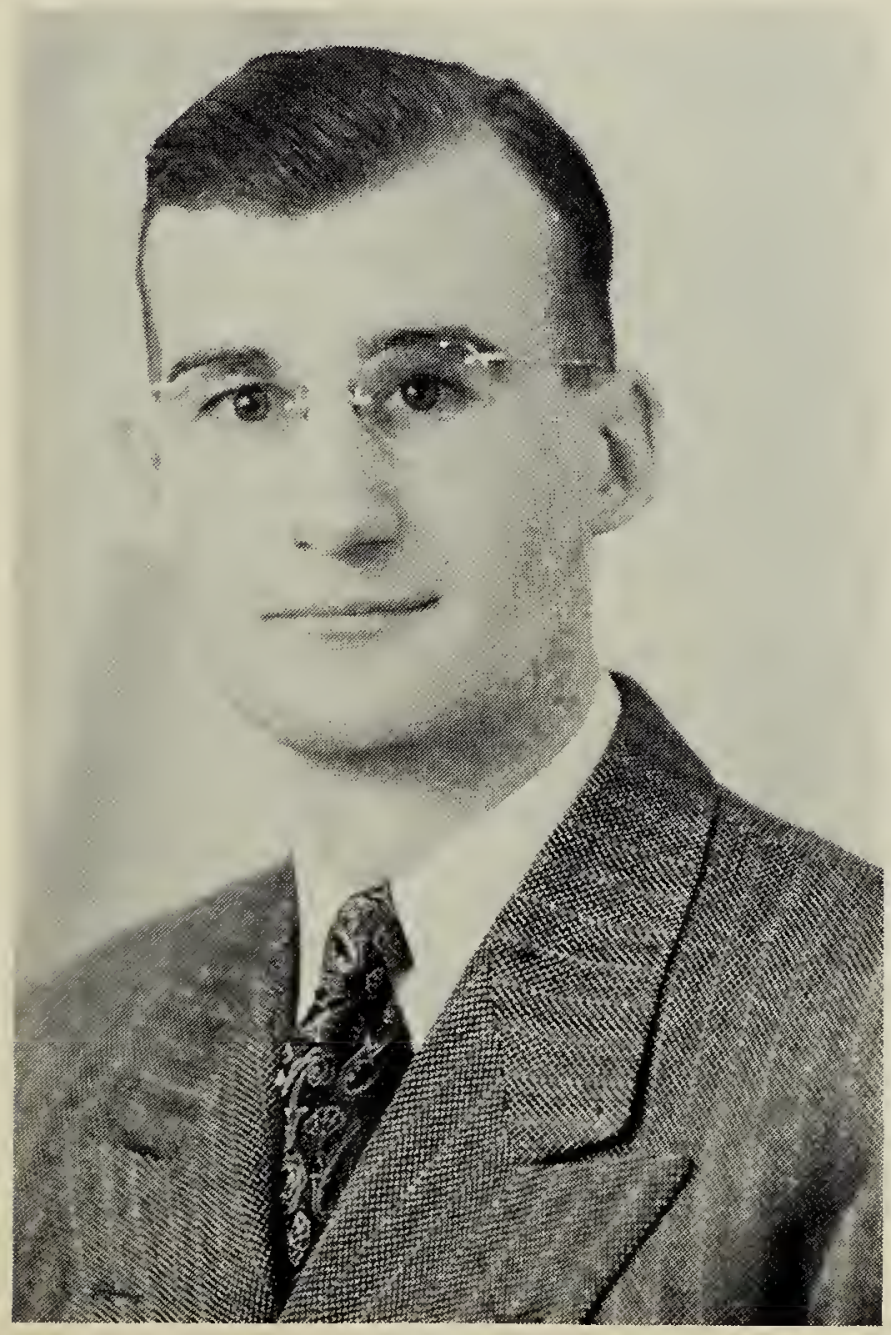

Edwin William Brooman was born at Prince Albert on 11 September 1914. $\mathrm{He}$ once told me that his interest in nature was "sparked" by Frank Lund, a Prince Albert taxidermist, and "fanned" by $O$. C. Furniss, one of his teachers. He began a collection of birds' eggs at age 10 , as boys with outdoor interests often did in those years. Often on his boyhood rambles he was accompanied by Elmer L. Fox. He began keeping records in 1934 .

Ed graduated from the Saskatoon Normal School in 1938, obtained his B.A. from the University of Saskatchewan in 1947, and his M.Ed. from the University of Arizona during a one-year sabbatical in 1959. He was viceprincipal at Queen Mary school, then principal of Prince Edward School in 1946 and of Prince Charles school from 1955 until his retirement in 1972. Although he took University courses in 